\title{
The development of Exceptional Case Marking in Romance with a particular focus on French*
}

\author{
Michelle Sheehan, Anglia Ruskin University
}

michelle.sheehan@anglia.ac.uk

\begin{abstract}
This paper traces the development of so-called Exceptional Case Marking (ECM) under perception, permissive and causative verbs in Romance. Synchronically, we can observe various patterns in the distribution of ECM complements under these verbs. In Portuguese and Spanish, ECM is often possible under all permissive and causative verbs, whereas in French, Catalan and Italian it is usually restricted to perception and permissive verbs. A detail that has not been much discussed is the fact that, for many speakers, ECM with a given verb is often restricted to contexts in which the embedded 'subject' is a clitic. Some speakers of Modern French display this pattern with the verb faire 'make', for example (Abeillé, Godard and Miller 1997). In this paper, I claim that laisser 'let' probably also displayed this pattern in Middle French. In Old French, however, what appears to be the opposite pattern is observed. Following Pearce (1990), I attribute this to the morphological variability of dative case in Old French. I propose a case-based analysis of the clitic ECM pattern, whereby ECM complements in Romance are phases unlike clause union complements (see Sheehan and Cyrino 2018). Where such complements are embedded under light verbs, the Phase Impenetrability Condition (Chomsky 2001) prevents accusative case from being assigned to the lower subject except in instances of cliticization. When the matrix verb is reanalysed as a full verb, however, v becomes the case-assigning head and so ECM becomes generally available, regardless of the clitic/non-clitic status of the causee.
\end{abstract}

Keywords: phases, diachrony, case, Agree, Phase Impenetrability Condition, ECM, verbs of perception, causatives, permissives, faire-infinitif, faire-par

\section{Complements of Modern French causative perception verbs}

\subsection{The basic patterns}

Three kinds of non-finite complementation are attested with causative, permissive and perception verbs in French: faire-infinitif(1a), faire-par (1b) and Exceptional Case Marking ECM (1c) (see Kayne 1975; Hyman and Zimmer 1976; Abeillé, Godard and Miller 1997 amongst many others). Verbs of perception (e.g., voir 'see') and the permissive verb laisser 'let' can select all three kinds of complements. The differences are clearest when the complement of laisser/voir is transitive and the causee is a full DP. In such contexts, the causee surfaces as (a) a dative, (b) an oblique by-phase or (c) a bare preverbal DP:

Transitive complement with DP causee

(1) a. Ce gâteau, Marie l'a laissé/vu manger à Chris.
that cake Marie it=has let/ seen eat.INF DAT Chris
b. Ce gâteau, Marie l' a laissé/vu manger par Chris.
that cake Marie it=has let/ seen eat.INF by Chris

\footnotetext{
* This work was inspired by joint work with Sonia Cyrino, Anna Pineda and Norma Schifano. Thanks to all of them for being so inspiring! Thanks also to Gigi Andriani, András Bárány, Anders Holmberg, David Pesetsky, Rodrigo Ranero, Ian Roberts, Maggie Tallerman, Sten Vikner, Jenneke van der Wal, Jim Wood and especially Adam Ledgeway, for discussing aspects of this work with me. Thanks also to Louise Raynaud for helping with the French data. All errors are my own, of course.
} 

c. Ce gâteau, Marie a laissélvu Chris le manger. that cake Marie has let/ seen Chris it=eat.INF
'As for that cake, Marie let/saw Chris eat it.'

In faire-infinitif and ECM contexts, the causee can also be realised as a clitic (2), but there is no oblique clitic to realise by-phrase causees in the FP construction. In both faire-infinitif and ECM contexts, clitic causees must climb to the clause hosting the causative/perception verb. In transitive contexts, accusative clitics associated with the embedded verb only climb to the main clause where the causee is dative (2a), but not in ECM contexts (2b-c). This suggests that the ECM construction is more bi-clausal than the faire-infinitif (Kayne 1975, Rosen 1992, Guasti 1993):

Transitive complement with clitic causee (no clitic for par 'by' phrase)

(2) Ce gâteau, Marie le lui a a laissé/vu manger
that cake Marie it=him.DAT= has let/l seen eat.INF
b. Ce gâteau, Marie l' $\quad a$ laissé/vu le manger.
that cake Marie him.ACC= has let/ seen it=eat.INF
'As for that cake, Marie saw him eat it.'
c. *Ce gâteau, Marie l'a laissé/vu Chris manger.
that cake Marie it=has let/ seen Chris eat.INF
'As for that cake, Marie let/saw Chris eat it.'

In intransitive contexts, full DP causees are realised as bare (accusative), with the difference between faire-infinitif/ faire-par (3a), and ECM (3b) reduced to the postverbal vs preverbal placement of the causee:

Intransitive complement with DP causee

(3) a. Marie a laissél entendu parler Chris.

Marie has let/ heard speak.INF Chris

b. Marie a laissél entendu Chris parler.

Marie has let/ heard Chris speak.INF

We know this, in part, because of the semantic differences between these orders (see below), but also because only post-verbal causees are possible with faire, which, for all speakers disallows ECM with full DP causees, but permits faire-infinitif/faire-par:

Intransitive complement with DP causee
(4)
a. Marie a fait parler Chris.
Marie has made speak.INF Chris
$\begin{array}{llll}\text { b. *Marie a fait } & \text { Chris parler. } \\ \text { Marie has made } & \text { Chris speak.INF }\end{array}$

Where the embedded verb is intransitive and the causee is a clitic, the causee must be realised as an accusative clitic and it has been argued that examples like (5) are therefore three-way ambiguous, a point to which we return below:

Intransitive complement with clitic causee (three-way ambiguity)

(5) Chris, Marie l' a laissél entendu parler.

Chris Marie him.ACC=has let / heard speak.INF

'As for Jean, Marie let/heard him speak.' 


\subsection{The structure of these complements}

The earliest generative studies of Romance causatives, posited transformations from biclausal structures to clause union with the faire-par and faire-infinitif (see Aissen \& Perlmutter 1976). However, there has been an increasing tendency to take a base-generated approach to clause union whereby the faire-par and faire-infinitif simply involve the embedding of truncated clauses (see Burzio 1986, Rosen 1992, for early versions of this approach, and Ciutescu 2018 for a recent dissenting voice). I adopt the essentials of the analysis of the faireinfinitif and the faire-par in Folli \& Harley (2007) whereby the faire-par is the smallest kind of complement, a nominalised VP lacking a true external argument and the faire-infinitif is a vP containing an external argument but lacking a Voice projection (see also Guasti 2017). For ECM complements, I adopt the idea that Romance ECM complements are larger, containing at least a Voice projection, though not as large as TPs (see Sheehan and Cyrino 2018, contra Guasti 1993).

This gives us the following typology of complement types with Romance causative/permissive/perception verbs:

(6) Structure of the complements of causative/permissive/perception verbs
a. Faire-par
laisser [vp [vp manger le gâteau] [pr par Jean]]
b. Faire-infinitif
laisser [vP v [vp manger le gâteau] [DP à Jean]]
c. ECM
laisser [voiceP être [vP v [vP arrêtés [DP les manifestants]]]]

Following much recent work, I assume that auxiliary verbs enter the derivation as Voice/aspect heads in a fixed functional sequence (following Ross 1969; Adger 2003; Cinque 2003, Bjorkman 2011; Sailor 2014) and that French être 'be' realises the Voice head in passives.1 As expected, no auxiliary verbs are possible in the complements of faire-par and faire-infinitif as these complements are simply too small to host Voice/aspect projections:2

$$
\begin{array}{lll}
* I I \quad a & \text { laissé } & \text { être descendu son ami par la police. } \\
\text { he has let } & \text { be shot.down his friend by the police }
\end{array}
$$

(Kayne $1975: 251)$

ECM complements, on the other hand more easily contain the passive Voice auxiliary and (in some cases) aspectual auxiliaries so can be VoiceP/progP/perfP (though this needs careful investigation on a case-by-case basis) (see Sheehan and Cyrino 2018 on ECM complements in English and Brazilian Portuguese):3

\footnotetext{
1 A potential issue, which I put to one side here is the status of the se 'self' morpheme in French. It is well known that si is banned under fare in the Italian faire-infinitif (Burzio 1986) and the same is true of European Portuguese se (Gonçalves 1999), but not of French se (Zubizarreta 1985).

2 Cinque (2003) actually claims that examples equivalent to (7) are bad because such examples are monoclausal and the passive auxiliary is merged above causative verbs in the universal functional sequence. The availability of Voice auxiliaries in ECM complements, in his terms, is due to their non-mono-clausal nature. There are challenges for this approach, however, from: (i) the fact that passives of causatives are severely restricted in Romance and Germanic languages, both in ECM and clause union contexts (see Sheehan and Cyrino 2018) and (ii) the fact that verbs such as volere can both precede and follow fare in Italian (with interesting restrictions), calling into question the strictly mono-clausal status of clause-union contexts (see Schifano and Sheehan 2018 for discussion).

3 In fact, Santorini and Heycock, note that the passive auxiliary être 'be' is relatively more acceptable under laisser in the faire-infinitif construction than under faire so there is more to be said here. They agree, though that it is most natural in the ECM construction.
} 
$\begin{array}{llll}\text { ?II a laissé sa fille } & \text { etre embrassée } & \text { par Jean. } \\ \text { he has let his daughter be.INF kissed } & \text { by Jean }\end{array}$

'He let his daughter be kissed by Jean.'

(Kayne $1975: 252$, fn. 61)

Another difference between the three complement types which falls out from these structural differences is the status of the causee. External argument causees are obligatory in the faireinfinitif and ECM complements as vP is obligatorily projected, but they are famously optional in the faire-par construction (9), and where present have the status of adjuncts, being unable to bind PRO or anaphors (Zubizarreta 1985, Rosen 1992, Guasti 1993, Folli and Harley 2007; Guasti 2017; building on Burzio 1986; but see also Pearce 1990).4

Omission of causees (possible with transitive/unergatives only)
a. Ce gâteau, Marie l'a laissél vu manger. that cake Marie it=has let/ seen eat.INF
b. Le professeur fait étudier en silence the teacher makes.INF study.INF in silence
'The teachers makes people study in silence.'
c. *Avec son système d'amendes, le professeur fait arriver à l'heure. [unacc] with her system of fines the teacher makes arrive.inf at the time

The ungrammaticality of (9c), I assume, is due to the fact that internal arguments are contained within VP and so are obligatory even in the faire-par construction. Only external arguments base generated outside VP can be omitted where VP is embedded (9a-b).

The question arises, however, how we know that the (9a-b) are instances of faire-par rather than faire-infinitif or ECM. The answer is that, as Kayne (1975) showed, faire-par is incompatible with non-passivisable idioms and so too are omitted causees:

Causee-less examples pattern with faire-par-non-passivisable idioms not possible

(10) a. Jean a fait casser la croûte à sa famille / *par sa famille. Jean has made break the crust DAT his family/ by his family 'Jean made his family have a snack.'

b. *Jean a fait casser la croûte. Jean has made break the crust Intended: 'Jean made people have a snack.' ～(Kayne 1975: 236)

These facts, taken together, suggest that examples (9a-b) are instances of faire-par and that they involve embedded VPs lacking an external argument.

The analysis also makes sense of why ECM becomes possible only where the complement of these verbs is a VoiceP, once fairly common assumptions about case theory are adopted. ProgP/VoiceP have been independently argued to constitute the v-related phase (see Wurmbrand 2012; Ramchand and Svenonius 2014; Aelbrecht and Harwood 2015; Harwood 2015 on English). If Voice is also the source of accusative case then this explains why in ECM contexts we find two domains for accusative case, whereas in faire-par and faire-infinitif we find only one (hence 'clause-union'). Note that, on this approach, the three

\footnotetext{
4 Adam Ledgeway (personal communication) asks whether unaccusatives are limited to the faire-par construction or whether they are also possible in the faire-infinitif. This is a difficult question to answer and it depends partly on whether one thinks that unaccusatives also project $\mathrm{v}$, even where no external argument is projected, which relates to the question of whether they are phasal or not (see Legate 2003). What is crucial for my purposes is that VP can be embedded under faire, without any higher projections. I leave the question of whether an unaccusative vP can also be embedded open here. It ought to be possible to ascertain this using semantic tests.
} 
functions of (i) introducing the external argument; (ii) assigning accusative case and (iii) delimiting a phase are split between the two verbalising heads in slightly different ways from in some previous approaches: v does (i) and Voice (ii)-(iii).5 See Sheehan \& Cyrino (2018) for a defense of this proposal for English and Romance langauges.

Taking phases to determine locality in syntax, the lack of Voice in clause union contexts also explains why there is a single domain for cliticization, hence the obligatory nature of object clitic climbing in (11a-b). Conversely, the ban on object clitic climbing in (11c) can be attributed to the fact that a phase boundary intervenes between the object clitic and matrix verb. We return to the cliticization of the causee in ECM contexts in Section3. No clitic climbing of the embedded object in ECM contexts:

(11) a. *Ce gâteau, Marie a laissé/vu le manger à Chris.

that cake Marie has let/ seen it=eat.INF DAT Chris

b. *Ce gâteau, Marie a laissélvu le manger par Chris.

that cake Marie has let/ seen it=eat.INF by Chris

c. *Ce gâteau, Marie l' a laissé/vu Chris manger.

that cake Marie it=has let/ seen Chris eat.INF

'As for that cake, Marie let/saw Chris eat it.'

This assumes, of course, that cliticization does not have access to phase edge escape hatches. In fact, it is probably the case that no A-movement operations can access phase-edge escape hatches (eee Sheehan and Cyrino 2018). As Ian Roberts (personal communication) notes, if clitics always adjoin to head positions, a ban on excorporation has the same effect here, as once a clitic has adjoined to any head, even a phase head, it will be blocked from moving further.6

Following the arguments in Pineda and Sheehan (2020), we assume that both the causee and the embedded theme receive case from the matrix Voice head in the faire-infinitif. For this reason, the Person Case Constraint (PCC) bans any kind of dative causee in the presence of a local (1st/2nd person) embedded theme (see Postal 1981, Postal 1989; Rezac 2008, Rezac 2009; Sheehan 2020).

PCC effects in causatives

(12) a. *Je vous lui

laisserai voir

I you.ACC $=3$ S.DAT $=$ let.1S.FUT see

Intended: 'I will let her see you. (Rezac 2008: 66 ; citing Postal 1981 ; Quicoli 1984)

5 For example, in Pylkkänen (2008) Voice fulfils all three of these functions where Voice and v are split, though they can also be bundled together (see Harley 2013, Harley 2017 for discussion). As Ian Roberts (persona communication) notes, this idea is supported, for English, by Merchant's (2013) evidence of voice-mismatches under ellipsis:

(i) This system can be used by anyone who wants to use it.

The ellipsis site is below Voice and the EA is targeted, so the latter must be introduced lower than Voice. 6 Adam Ledgeway asks about the status of $s e$ 'self', which appears to be an exception in this respect in not undergoing obligatory clitic climbing:

No clitic climbing of se:

(i) Marie fait se raser Jean

Marie makes $\mathrm{SE}=$ shave Jean

'Marie makes Jean shave.'

The status of SE in reflexives remains controversial. It has been claimed to be a valency reducing morpheme (Reinhart 1997, Reinhart and Siloni 1999), an external argument (McGinnis 2004) or an internal argument (Schäfer 2017). If SE is arguemental, then this behaviour is unexpected. I leave this matter to one side here but note that, as mentioned above, in Italian and Portuguese, SE would be suppressed in such contexts, adding further intrigue to the plot. 

b. Je vous laisserai voir par elle.
I you.ACC $=$ let.1S.FUT see.INF by her
c. Je la laisserai vous voir.
I her.ACC $=$ let.1S.FUT you.ACC $=$ see
'I will let her see you.

In the spirit of many analyses of the PCC, we assume that this effect results from the fact that the two internal arguments are licensed by a single functional head in the faire-infinitif (Anagnostopoulou 2003, 2005, Nevins 2007, Rezac 2008, Coon and Keine 2020). Note that no PCC effects arise with faire-par (11b) or ECM (11c) complements. This is because in faire-par the causee is an oblique by-phrase that so does not enter into any Agree relationship and in the ECM context, the causee and theme are licensed by different heads: the causee by matrix Voice and the theme by the embedded Voice head. Crucially, as Postal (1989) discusses at length, even full DP dative causees are blocked in the presence of a $1 \mathrm{st} / 2 \mathrm{nd}$ person embedded object in the faire-infinitif:

(13) a. *Marcel vous a fait épouser au médecin. Marcel you.ACC= has made marry to.the doctor Intended: 'Marcel had the doctor marry you.' one you.ACC=let.3S.FUT know.INF DAT Louise Intended: 'We will let Louise meet you.
b. *Onvous laissera connaître à Louise.
c. Marcel l' a fait épouser au médecin. Marcel her.ACC $=$ has made marry to.the doctor 'Marcel had the doctor marry her.' $\quad$ (Postal 1989: 2)

The pattern in (13) shows that full DPs also agree with matrix Voice so that this is not merely an effect of clitic clusters but rather of case licensing (see Sheehan 2020 for further discussion).

The following table summarises some of the main differences between the three complement types discussed here, all of which can be attributed to their different sizes.

Table 1. Core syntactic properties of these reduced complements (see Kayne 1975; Burzio 1986; Pearce 1990)

\begin{tabular}{|l|l|l|l|}
\hline & Faire-par & Faire-infinitif & ECM \\
\hline $\begin{array}{l}\text { Transitive } \\
\text { complement }\end{array}$ & $\begin{array}{l}\text { postverbal by } \\
\text { phrase causee }\end{array}$ & $\begin{array}{l}\text { postverbal DAT } \\
\text { causee }\end{array}$ & $\begin{array}{l}\text { preverbal ACC } \\
\text { causee }\end{array}$ \\
\hline $\begin{array}{l}\text { Intransitive } \\
\text { complememt }\end{array}$ & $\begin{array}{l}\text { postverbal ACC } \\
\text { causee }\end{array}$ & $\begin{array}{l}\text { postverbal ACC } \\
\text { causee }\end{array}$ & $\begin{array}{l}\text { preverbal ACC } \\
\text { causee }\end{array}$ \\
\hline Causee omission & $\begin{array}{l}\text { Y- external } \\
\text { arguments }\end{array}$ & N & N \\
\hline $\begin{array}{l}\text { Clitic climbing of } \\
\text { causee }\end{array}$ & $\begin{array}{l}\text { NA - causee } \\
\text { cannot be clitic }\end{array}$ & Y obligatory & Y \\
\hline $\begin{array}{l}\text { Clitic climbing of } \\
\text { embedded object }\end{array}$ & Y obligatory & Y obligatory & $\mathrm{N}$ \\
\hline PCC & N & Y & $\mathrm{N}$ \\
\hline
\end{tabular}

\subsection{The special case of faire}

For many French speakers, ECM complements of faire 'make' are simply ungrammatical (Kayne 1975:ch3). There is considerable variation though and many authors, including 
Kayne (1975: ch3, fn 30), have noted that ECM is possible for some speakers with faire, but only where the causee is a clitic (Grevisse 1969: 1064; Hyman and Zimmer 1976; Abeillé, Godard and Miller 1997):

\section{ECM causatives under faire}

(14) a. Le professeurles fera lire Proust.

the teacher them.ACC $=$ make.FUT read.INF Proust

'The teacher made them read Proust.'

b. Le professeur les fera le lire.

the teacher them.ACC=make.FUT it $=$ read.INF

'The teacher made them read it.' (Abeillé, Godard and Miller 1997: 65)

c. *Paulfera les élèves de seconde lire Proust.

Paul make.FUT the pupils of second read.INF Proust

'The teacher made the second years read Proust.'

Clitic ECM also seems to be possible in intransitive contexts, though it is harder to detect. As noted above, object clitic climbing is obligatory in the faire-infinitif and banned in ECM contexts in French (Kayne 1975). Assuming this is also the case with partitive clitics, then the apparent optionality of clitic climbing in (15) can actually be attributed to the availability of two structures: the faire-infinitif in (15a) and ECM in (15b), as Abeillé et al. note:

(15) a. Le professeur les en a fait discuter.

the teacher them.ACC $=$ PART $=$ has made discuss.INF

b. Le professeur les a fait en discuter

the teacher them.ACC $=$ has made PART $=$ discuss.INF

'The teacher made them talk about it.' (Abeillé, Godard and Miller 1997: 63)

I will call this complementation pattern clitic ECM, for ease of reference.

The availability of clitic ECM with faire is semantically conditioned. The semantic differences between faire-par and faire-infinitif are well known (see Kayne 1975; Burzio 1986; Guasti 1993, Guasti 1996; Folli and Harley 2007). In simple terms, the faire-par construction is about getting something done, whereas the faire-infinitif is about getting someone to do something:

(16) a. II fera courir le 100 mètres par Jean-Jacques.

he make.FUT run.INF the 100 metres by Jean-Jacques

'He'll have the 100 meters run by Jean-Jacques.'

b. II fera courir le 100 mètres à Jean-Jacques.

he make.FUT run.INF the 100 metres DAT Jean-Jacques

'He'll have Jean-Jacques run the 100 meters.' $\quad$ (Kayne 1975: 240)

The differences between ECM and faire-infinitif are less well studied. In French, clitic ECM under faire is reported only to be felicitous where the causee is agentive but forced or coerced to act by the causer/cause (Kayne 1975: ch3, fn 30; Authier \& Reed 1991; Bailard 1982; Abeillé et al. 1997). For this reason, where the embedded verb is an agentive verb such as dévorer 'devour' an accusative causee is possible (17), but where it is a non-agentive verb such as aimer 'love', only a dative causee is acceptable (18):

(17) la lueur d'angoisse qui réveille le tigre et luil le fait dévorer the glimmer of worry that awakens the tiger and it.DAT/.ACC makes devour.INF le dompteur 
the tamer

'The glimmer of worry that awakens the tiger and makes it eat its tamer.' (Bailard 1982:52)

(18) Faites-leur/ -\#les aimer Proust!

make.2PL.IMP=them.DAT/.ACC love.INF Proust (Abeillé, Godard and Miller 1997: 66)

A meaning contrast between ECM and clause union is also observed with laisser 'let' in French. As Kayne (1975: 232) notes, (18a) implies "a degree of collusion or of intentionality on the part of the guard", which is lacking in (18b):

(19) a. Le gardien a laissé le prisonnier s'échapper.

the warden has let the prisoner $\mathrm{SE}=$ escape.INF

'The warden let the prisoner escape (intentionally).'

b. Le gardien a laissé s'échapper le prisonnier.

the warden has let $\mathrm{SE}=$ escape.INF the prisoner

'The warden let the prisoner escape (unintentionally).'

(Kayne 1975: 232)

It is not clear whether this is the same semantic contrast at some level of abstraction and nor is it clear to what extent the semantic contrast observed with voir is parallel. This contrast is reported to involve "a stronger sense of actual visual perception of Jean" in (19a) when compared with (19b) (Kayne 1975: 232, see also Guasti 1993, Higginbotham 1993):

(20) a. $J^{\prime}$ ai vu Jean faire des bêtises.

I have seen Jean do.INF of.the stupidities

'I've seen John do some silly things.'

b. J'ai vu faire des bêtises à Jean.

I have seen do.INF of.the stupidities DAT Jean

'I've seen John do some silly things.'

(Kayne 1975: 232)

For our purposes, what is crucial is that the semantic contrast between clitic ECM vs clause union, coupled with the syntactic differences already noted (notably the presence/absence of clitic climbing), strongly suggests that the clitic ECM pattern is not merely a surface morphological effect, but rather a structural difference.

More research is needed to establish the sociolinguistic factors which determine the availability of clitic ECM under faire in French. This is, unfortunately, beyond the scope of the present study, but it is certainly rejected by many speakers except in one particular context.7 As Abeillé, Godard and Miller (1997) note, the ECM structure becomes more generally possible in PCC-violating contexts in French (and the same appears to be true of the other Romance languages discussed below):

(21) a.Paulte fera nous expliquer la solution $d u$ problème.

Paul you $=$ make.FUT us= explain.INF the solution of. the problem

'Paul will make you explain to us the solution to the problem.'

(Abeillé, Godard and Miller 1997: 64)

7 Interestingly, this suggests that ECM under faire is on the decrease rather than the increase and this has, in fact, been claimed in the literature (see Martineau 1990 who attributes this claim to Danell 1979 via St-Amour 1983). 
Even speakers who reject examples like (14a-b) often accept (21). In other words, the ECM construction is available for many as a PCC repair, where the faire-infinitif is blocked (as discussed above). These patterns are summarised in Table 2.

Table 2. French complementation patterns

\begin{tabular}{|l|l|l|l|}
\hline & faire 'make' & laisser 'let' & voir 'see' \\
\hline Faire-infinitif & $\mathrm{Y}$ & $\mathrm{Y}$ & $\mathrm{Y}$ \\
\hline Faire-par & $\mathrm{Y}$ & $\mathrm{Y}$ & $\mathrm{Y}$ \\
\hline ECM & $\begin{array}{l}\text { PCC contexts } \\
1 \% \text { clitics only }\end{array}$ & $\mathrm{Y}$ & $\mathrm{Y}$ \\
\hline
\end{tabular}

This clitic ECM pattern poses a theoretical challenge. First, it suggests that the unacceptability of ECM under faire in (14c) is not a matter of selection alone. Faire clearly can select for an ECM complement for (some) French speakers, but the result is only grammatical if that complement contains a pronominal subject (for a subset of speakers) or a clitic causee and a 1 st $/ 2$ nd person theme (for many more). Selection is usually taken to be a relationship between a head and the head it selects, not between a head and the arguments of that complement, making selection an unlikely explanation.

Nor can the pattern be a matter merely of the availability or non-availability of accusative case under faire. According to Pineda and Sheehan's (2020) analysis, the verb faire can assign accusative case not only where it functions as a lexical verb but also in the faire-infinitif construction, where it has a similar (though distinct) meaning as a causative verb (see also Belletti and Rizzi 2012). If this is the case then accusative case should also be available with ECM complements (VoicePs). Finally, the pattern cannot be attributed to a more general property of the language which serves to block full ECM, because other verbs such as laisser 'let' permit ECM with full DPs in the same language. Rather, there must be something about the status of faire as it occurs in this particular syntactic context which means that ECM is possible only with clitics. In section 3, I sketch an analysis of the clitic ECM pattern as a simple effect of phase theory. First, though, I present further examples of this pattern in other Romance languages in order to make the case that it is robustly attested pattern, rather than a simple quirk of French faire.

\section{Clitic ECM patterns in other Romance varieties}

\subsection{Italian}

Standard Italian generally disallows ECM complements with fare 'make': causees (clitic or otherwise) cannot usually be accusative where an embedded predicate is transitive (see Burzio 1986; Guasti 1993, Guasti 1996; Folli and Harley 2007 and many others):
a. Gianni glil $\quad *$ ' ha fatto lavare $i$ piatti.
G. him.DAT/ *ACC $=$ has made wash the dishes
'Gianni made him wash the dishes.'
b. Maria ha fatto lavare $i$ piatti *(a) Gianni.
Maria has made wash the dishes DAT Gianni
'Maria made Gianni wash the dishes.'

Burzio (1986: 232) notes that ECM is relatively acceptable for some speakers, however, as long as the causee is a clitic. This clitic ECM pattern is parallel to the French pattern, though it appears to be less wide-spread in Italian: 

a. ?Maria l' ha fatto riparare la macchina
Maria him. $\mathrm{ACC}=$ has made repair.INF the car
'Maria made him repair the car.'
b. *Maria ha fatto Gianni riparare la macchina
Maria has made Gianni repair.INF the car
'Maria made Gianni repair the car.'

Once again, it seems that clitic ECM becomes more widely available as in PCC contexts, where dative subjects are not possible, as discussed by (Schifano \& Sheehan 2017):

ECM more acceptable in PCC contexts

(24) \%Lo/ *gli fece picchiarmi

3SG.ACC/ 3SG.DAT made beat.INF.=1SG.ACC

'She made him beat me.'

Prescriptively lasciare 'let' permts all three kinds of complements in standard Italian.

However, it appears to be the case that some (northern) speakers allow ECM under lasciare 'let' only with clitic causees (see Burzio 1986: 229, 287):8
a. $\% \mathrm{Ho}$
lasciato Giovanni mangiare
la mela.
have.1SG let Giovanni eat.INF the apple
'I let Giovanni eat the apple'
b. $L^{\prime} \quad$ ho lasciato mangiare la mela
him.ACC=have.1SG let eat.INF the apple
'I let him eat the apple'

All three kinds of complements are possible with verbs of perception in Italian, giving the complementation patterns schematised in Table 3.

Table 3. Italian complementation patterns

\begin{tabular}{|l|l|l|l|}
\hline & faire 'make' & laisser 'let' & voir 'see' \\
\hline Faire-infinitif & $\mathrm{Y}$ & $\mathrm{Y}$ & $\mathrm{Y}$ \\
\hline Faire-par & $\mathrm{Y}$ & $\mathrm{Y}$ & $\mathrm{Y}$ \\
\hline ECM & $\begin{array}{l}\mathrm{N} / \% \mathrm{PCC} / \% \text { clitics } \\
\text { only }\end{array}$ & clitics only/\%DPs & $\mathrm{Y}$ \\
\hline
\end{tabular}

Once again, it is not clear which sociolinguistic variables condition the availability of ECM in standard Italian, but what is striking is that we find the same clitic ECM pattern described for French. In fact the clitic ECM is found in Italian with the permissive verb as well as with causative fare. The patterns are different, however. All speakers allow clitic causees with lasciare 'let' and what varies is whether they also allow full DP causees, whereas only a minority of speakers allow even clitic causees under fare 'make' and none allow full DPs.

8 As Adam Ledgeway (personal communication) notes, there are other regional differences regarding the use of these verbs. Southern dialects, and hence often regional southern Italian, often use fare 'make' rather than lasciare 'let' in permissive contexts, for example:

(i) non si vuole far convincere neg SE wants make convince 'She doesn't want to let herself be persuaded.' 


\subsection{Catalan9}

Catalan also makes use of all three kinds of complements described in Section 1.1, but in slightly different ways (see Solà 1994; Torrego 1998; Villalba 1992; Alsina 1992, Alsina 1997, Alsina 2002/2008; Sheehan \& Cyrino 2016; Pineda \& Sheehan 2020). The most widely accepted complement of fer 'make' is the faire-infinitif. Faire-par is possible in Catalan only where the causee is supressed for many speakers (Villalba 1992, 359, fn 9; 328, fn 17), but see also Alsina (1996).

(26) Els meus pares van fer construir una casa (*per aquests arquitectes) the my parents go.3PL make build a house by these architects 'My parents had a house built.'

Such examples nonetheless share the core properties of faire-par, unlike superfiically parallel examples in Portuguese and some varieties of Spanish (Sheehan \& Cyrino 2016)

For many speakers, ECM is not possible under fer, but again, some speakers allow the clitic ECM pattern, as in French and Italian (Solà 1994: § 9.3; Torrego 1998:§3).

$\%$ Ell $\quad \boldsymbol{a} \quad$ feia baixar les escales de les criptes.
he her.ACC $=$
'He made descend her descend the stairs of the crypts.'

As in French, this is a minority/variable pattern unlike faire-infinitif. Consider Pineda \& Sheehan's (2020) survey data with fer:

$$
\begin{array}{cllll}
\% \text { ' } & \text { he } & \text { fet } & \text { rentar els plats. } \\
\text { him. } \mathrm{ACC}= & \text { have } & \text { made } & \text { wash the dishes }
\end{array}
$$

'I have made him wash the dishes.'

$\boldsymbol{L} \boldsymbol{i}$ he fet rentar els plats.
him.DAT= have made wash the dishes
'I have made him wash the dishes.'

$\% L^{\prime}$ he fet escombrar el
him.ACC $=$ have made sweep
'I have made him sweep the dining room.'

$\begin{array}{lllll}\boldsymbol{L} \boldsymbol{i} & \text { he fet escombrar } & \text { el menjador. } \\ \text { him.DAT }= & \text { have made sweep } & \text { the dining room }\end{array}$

ECM with full DP causees is never possible under fer. With deixar 'let' there is also variation. While some speakers are reported to allow full ECM, others are restricted to clitic ECM, in parallel with the pattern discussed above for Italian (Alsina 2002/2008: 2424, fn. 17)

$$
\begin{aligned}
& \text { *El Joan ha fet } \quad \text { (a) la Maria rentar els plats. } \\
& \text { the Joan has made } \\
& \text { 'Joan made Maria wash the dishes.' }
\end{aligned}
$$
(33) \%Hauriem
de deixar la Maria
explicar la seva proposta
Should.1PL of let the Maria
explain the her proposal

(Alsina 2002: 2424) 
Again, it is striking that the same clitic ECM pattern is attested in Catalan with permissive and causative verbs. Verbs of perception permit both faire-infinitif and ECM (as in French and Italian):

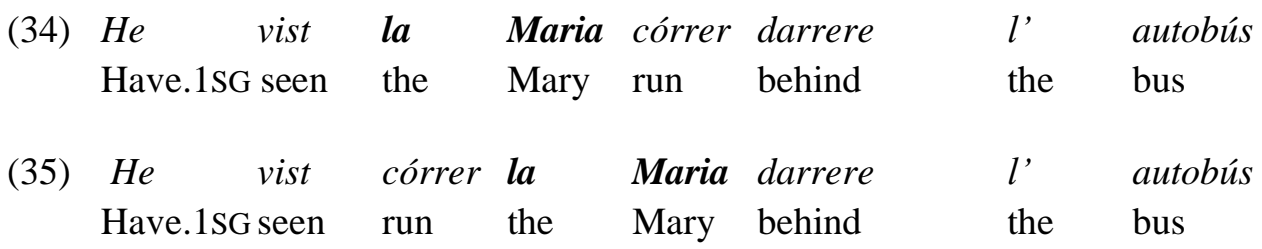

In Catalan too, clitic ECM appears to become more acceptable in PCC contexts, where the embedded object is 1 st $/ 2$ nd person, but survey data are needed to ascertain how generally acceptable such examples are:
va fer
insultar.
(Bonet 1991: 195)
1S.ACC $=3$ SM.DAT $=$ goes make.INF insult.INF
Intended: 'He/she made him insult me.'
b. \%El va fer insultar-me
3SM.ACC $=$ goes make.INF insult.INF $=1$ S. ACC
'He/she made him insult me.'

Again, further investigation is required to identify the sociolinguistic variables conditioning the availability of ECM in Catalan but what is striking is that the clitic ECM pattern is again attested with both causative and perception verbs, though in different ways, as discussed above for Italian. This is summarised in Table 4.

Table 4. Catalan complementation patterns

\begin{tabular}{|l|l|l|l|}
\hline & faire 'make' & laisser 'let' & voir 'see' \\
\hline Faire-infinitif & $\mathrm{Y}$ & $\mathrm{Y}$ & $\mathrm{Y}$ \\
\hline Faire-par & $\mathrm{Y}$ (no overt by phrase) & $?$ & $?$ \\
\hline ECM & $\begin{array}{l}\text { N//\%PCC only } \\
\% \text { clitics only }\end{array}$ & clitics only/\%DPs & $\mathrm{Y}$ \\
\hline
\end{tabular}

\subsection{Spanish and Portuguese}

In relation to Spanish and Portuguese, ECM is much more developed. In Brazilian Portuguese, clause union is no longer possible even under fazer 'make' and mandar 'have/order' (Cyrino 2010a; Cyrino 2010b; Bonfim and Salles 2016; Sheehan \& Cyrino 2016), and in European Portuguese and some Spanish varieties full ECM is possible with all perception/permissive and causative verbs (Strozer 1976; Davies 1992; Treviño 1994; Davies 1995; Torrego 2010, but see also Bordelois 1988 for a conservative variety). The Portuguese facts are further complicated by the fact that inflected infinitival complements with nominative subjects are also possible in both European and Brazilian Portuguese, and by the fact that, in Brazilian Portuguese, for independent reasons accusative clitics are increasingly replaced by full pronominals (identical to nominative pronouns) (Martins 2004; Martins 2018; Hornstein, Martins and Nunes 2008; Sheehan \& Cyrino 2018).

Davies (1992) shows that, in diachronic terms, ECM is an innovation which developed in the following way in these languages:

(37) The development of ECM in Spanish and Portuguese (Davies 1992) perception/permission > causation 
In transitive contexts, virtually all 'causees' are dative in Old Portuguese with all three verb types (causative/perception/permissive). In Middle Portuguese, however, the permissive and perception verbs begin to surface with accusative in transitive contexts. This ECM pattern is then extended to causative verbs (mandar/fazer) in Modern Portuguese, with just under 50\% of examples displaying this pattern with both DP and clitic causees. Unfortunately, in Davies' data, there are too few examples of permissive and perception verbs in Middle Portuguese to draw any conclusions about whether this development included a stage of clitic ECM. The history of Spanish shows the same pattern of development with the exception that the onset of ECM comes a little later, after the Middle Spanish period and, possibly as a result, ECM is has a narrower distribution in Modern Spanish than in Modern Portuguese. The added complication of differential object marking in Spanish means that it is not easy to ascertain whether Spanish ECM developed first with clitics or full DPs, as all transitive causees in Davies corpus are introduced by 'a'.

What is interesting about the diachronic development of Spanish and Portuguese is that the attested patterns partially mirror the synchronic patterns discussed above for French, Catalan and Italian. In all cases, there is a distinction between the causative verbs with which ECM is unavailable, limited to clitics or attested later, and the permissive/perception verbs with which it is more readily available or attested earlier. The synchronic patterns also suggest a further difference between the verbs of perception vs permissive verbs, based on modern Italian and Catalan. It is possible that the sparcity of historical data obscures this pattern diachronically.

Table 5: distribution of ECM and FI complements

\begin{tabular}{|l|l|l|l|l|l|l|}
\hline & Italian & Catalan & French & Spanish & $\begin{array}{l}\text { E. } \\
\text { Portuguese }\end{array}$ & $\begin{array}{l}\text { B } \\
\text { Portuguese }\end{array}$ \\
\hline SEE & FI/ECM & FI/ECM & FI/ECM & FI/ECM & FI/ECM & ECM \\
\hline LET & $\begin{array}{l}\text { FI/ } \\
\text { cl ECM/ } \\
\% \text { ECM }\end{array}$ & $\begin{array}{l}\text { FI/ } \\
\text { cl ECM } \\
/ \% \text { ECM }\end{array}$ & FI/ECM & FI/ECM & FI/ECM & ECM \\
\hline MAKE & $\begin{array}{l}\text { FI/ } \\
\% c l \text { ECM }\end{array}$ & $\begin{array}{l}\text { FI/ } \\
\% c l \text { ECM }\end{array}$ & $\begin{array}{l}\text { FI/ } \\
\text { cl ECM }\end{array}$ & $\begin{array}{l}\text { FI/\%ECM/ } \\
\% \mathrm{cl} \mathrm{ECM}\end{array}$ & FI/ECM & ECM \\
\hline MANDARE & $\begin{array}{l}\text { prep. } \\
\text { infinitive } 10\end{array}$ & $*$ & $*$ & $\%$ FI & FI/ECM & ECM \\
\hline
\end{tabular}

From this perspective, the clitic ECM pattern looks like an intermediate step in the extension of ECM, as illustrated by Table 5. A language first has the clause union pattern with these verbs then the clitic ECM patterns develops until finally full ECM becomes possible:

(38) Extension of ECM under causative/permissive/perception verbs

Clause union > clitic ECM > full ECM

10 As Adam Ledgeway notes, Italian has a much reduced/rarer 'mandare $a+$ infinitive' with a causative reading:

(i) $\begin{array}{lll}\text { Mi mandavano } & a & \text { chiamare } \\ 1 \mathrm{SG}=\text { sent.3PL.IMP } & \text { to } & \text { call.INF }\end{array}$

'They would have me sent for.'

This is clearly a different kind of complement again as it contains a preposition and requires an arbitrary null subject. He further notes that in some Italo-Romance varieties, including old Italian, we also find a gerundival complement in place of the infinitive under mandare 'order'. 
In the remainder of this paper, I propose an analysis of the clitic ECM pattern before considering its relevance to the history of French.

\section{Towards an explanation}

\subsection{More on ECM complements}

Recall, from Section 1.2., the proposed structure for the reduced complements of causative/permissive/perception verbs, adopted from Folli \& Harley 2007 and Sheehan \& Cyrino 2018):

(39) Structures of the complements of causative/permissive/perception verbs
a. Faire-par
laisser [vp [vp manger le gâteau] [Pp par Jean]]
b. Faire-infinitif
laisser [vP v [vp manger le gâteau] [DP à Jean]]
c. ECM
laisser [voiceP être [vP v [vP arrêtés [DP les manifestants]]]]

Something which remains unexplained by these structures is the word order of ECM complements, which, in modern varieties, at least, is always SV, even where the embedded verb is unaccusative/passive:

(40) (?)Le chef de police a laissé les manifestants être arrêtés. the chief of police has let the demonstrators be arrested 'The chief of police had the demonstrators arrested.'

(Santorini \& Heycock 1988: 39)

This word order implies that the causee must move either (i) to a position in the matrix clause (raising to object) or (ii) to a 'subject' position at the edge of the ECM complement (raising to subject) (Guasti 1993). I assume a raising-to-object account of this SV word order (see Sheehan \& Cyrino 2018 for further discussion). More specifically, the causee Agrees with matrix $v$, is assigned accusative case and then moves to matrix spec vP to satisfy an EPP feature on $\mathrm{v}$. The matrix verb, which has raised to $\mathrm{v}$, then moves higher, to the matrix Voice position, yielding the correct word order:

(41) ECM [voiceP laisser+v+Voice [vP [DP les manifestants] t t ... [voiceP être [vP v [vp arrêtés ti ]]]

Sheehan and Cyrino (2018) provide indirect evidence for a raising to object analysis from the ban on passivisation with Romance ECM, which they derive from phase theory.

Further potential evidence that such examples involve raising to object comes from the fact that no expletive/quasi-expletive subjects are possible under causative/perception verbs. If the SV order in ECM were due to raising to a subject position to satisfy an EPP in the ECM complement, then we might expect, in French at least, which disallows null subjects, that this position would display the same EPP-related properties as the canonical subject position. Instead, we find that expletives are impossible in ECM complements (Kayne 1975: 233):

(42) a. Je (*I') entends pleuvoir.

I it $=$ hear rain.inf

b. Elle ("'l) a regardé neiger.

she it=has seen snow.inf

c. Je $(* l) a i \quad v u$ pleuvoir pendant 48 heures.

I it=have seen rain.inf during 48 hours

d. Les savants sont maintenant capables de $(* \boldsymbol{l e})$ faire pleuvoir.

the wise are now capable of it make rain.inf 
'Scientists are now capable of making it rain.'

Of course, this could simply be because these embedded clauses are non-finite, or because French lacks object expletives more generally, as Adam Ledgeway (personal communication) notes. It is also as expected, however, if the canonical EPP is associated with a T-related projection and these ECM complements are too small to contain such a projection. Indeed, although passive auxiliaries are available in ECM contexts, aspectual auxiliaries are generally not (though this is subject to variation and so requires further investigation) (see Sheehan and Cyrino 2018).

There is a potential challenge for the raising-to-object view, however, from the distribution of negation. Negation is permitted in ECM complements in Italian (Guasti 1993), European Portuguese (Gonçalves 1999; Martins 2004), Spanish, Catalan (Villalba 1992; Tubino Blanco 2010) and French (Kayne 1975) (see also Ciutescu 2013 for a pan-Romance perspective). In most of these languages, there is a sharp contrast between ECM complements and clause union because in the latter context negation is ruled out. French permits clausal negation (somewhat marginally, sometimes) also with faire-infinitif/faire-par, however (Guasti 1993:80; Labelle 1996:15):
a. J'ai vu Pierre ne pas chanter
I have seen Pierre NEG not sing.INF.
'I've seen Pierre not singing'
b. ' $J$ ' ai vu ne pas chanter Pierre.
I have seen NEG not sing.INF Pierre
c. ?Cela a fait ne pas manger la soupe à l'enfant.
that has made neg not eat.INF the soup to the child
'That made the child not eat its soup'

As Ian Roberts (personal communication) notes, French allows double ne pas:

(44) Le film était tellement émouvant qu' on ne pouvaitpas ne pas pleurer.
the film was so moving that one NEG could not NEG
'The film was so moving that one could not help but cry.'

The second of these is probably constituent negation and the same could be true of (43c). The ungrammaticality of (43b) then, would have to due to a semantic incompatibility rather than a grammatical restriction. For this reason, it is not clear what to make of the negation patterns, especially in French, and I leave this matter to one side here. Note that it is crucial for the analysis of clitic ECM proposed here that the SV order with ECM complements results from raising to object rather than raising to subject, for reasons that will become clear in the next section.

\subsection{The clitic ECM pattern}

The question remains how we can account for the clitic-only ECM pattern attested in French, Italian and Catalan, repeated here as (45):
a. Le professeurles fera lire Proust.
the teacher them.ACC $=$ make.FUT read.INF Proust
'The teacher made them read Proust.'
b. Le professeur les fera le lire.
the teacher them.ACC=make.FUT $\mathrm{it}=$ read.INF
'The teacher made them read it.' $\quad$ (Abeillé, Godard and Miller 1997: 65) 


\section{c. *Paulfera les élèves de seconde lire Proust. \\ Paul make.FUT the pupils of second read.INF Proust \\ 'The teacher made the second years read Proust.'}

As discussed above, this cannot be attributed merely to selection, as heads do not select for the properties of the arguments contained in their complement. Nor can it be attributed to a general case-deficiency of the verbs in question, as where they surface in the faire-infinitif, they are able to assign accusative case, and in any case clitics presumably need to be case licensed too, especially as they display morphological case. Rather, the clitic ECM pattern must be a fact about the particular structure in which these verbs occur and some independent difference between clitics vs full DPs.

Interestingly a superficially similar pattern is described by Kayne (1981) for ECM under croire 'believe', whereby a full DP subject is banned but a clitic subject is marginally possible:
a. *Je crois Jean être le plus intelligent de tous. I believe Jean be.INF the most intelligent of all.PL b. ?Jele crois être le plus intelligent de tous. I him= believe be.INF the most intelligent of all.PL 'I believe him to be the most intelligent of all.'

(Kayne 1981: 356)

(Kayne 1981: 361, fn 16)

As Rooryck (2000) notes, however, clitic ECM in this context is extremely restricted, and apparently possible only where the embedded clause contains a comparative or superlative. As he notes, superlatives/comparatives have been argued to involve A-bar movement, and in fact, other kinds of A-bar movement feed ECM under croire 'believe' (and related verbs):
a. *Je le crois être maladelau lit avecla fièvre jaune.
I him= believe be.INF ill/ at.the bed with the fever yellow 'I believe him to be ill/in bed with yellow fever.'

(Rooryck $2000: 27$ )

b. Quel gargon crois/reconnais/constates- tu être le plus intelligent de tous? which boy believe/recognise/determine=you be.INF the most intelligent of all. 'Which boy do you believe/acknowledge/determine (to) be the most intelligent of all?'
c. Voilà la linguiste qu' on a cru/ dit avoir été mal comprise here.is the linguist.F that one has believed/said have.INF been badly understood 'This is the female linguist who they believed/said to have been misunderstood.'
d. *Cette personne a été cru(e)/ dit(e) avoir été mal comprise. this person has been believed.(F)/said.(F) have.INF been badly understood Intended: 'This person was believed/said to have been misunderstood.'

(Rooryck $2000: 29$ )

The contrast between (47b-c) and (47d) shows that ECM is possible only where the ECM subject undergoes A-bar movement and not A-movement. The pattern under faire 'make' is different. For speakers who accept clitic ECM under faire 'make', ECM is not usually fed by A-bar movement, the only exception being (48a), which is marginally possible:
a. ?Qui est-ce que tu as fait lire
Proust?
who is=this that you have made read.INF Proust
'Who did you make read Proust.'
b. */??Quels étudiants as- tu fait lire Proust?
which students have $=$ you made read.INF Proust
c. *Ce sont/*c' est les élèves de seconde que j'ai fait lire Proust. 
these are/ this is the pupils of second that I have made read.INF Proust

As passivisation of faire is independanly blocked (Burzio 1986), it is not possible to test whether A-movement feeds ECM here. The pattern in (48) suggests that under faire 'make', it is the pronominal status of the causee that is crucial, not whether it undergoes A-bar movement. I assume that the marginal acceptability of (48a) is due to the acceptability of clitic ECM, and that A-bar movement does not feed ECM under faire. The pattern is therefore subtly different from the pattern with croire 'believe' and I leave open here how to account for the distinct pattern described by Kayne/Rooryck.

My proposal is that the clitic ECM pattern is what we find where the matrix verb is a light verb rather than a lexical verb. Lexical verbs are instances of $\mathrm{V}$ which, in non-truncated clauses are dominated by external-argument-introducing little $\mathrm{v}$ and a phasal Voice head. I adopt the assumption that accusative case features originate on Voice (the phase head) but are inherited by v, all else being equal (Chomsky 2008). I further assume that light verbs differ from lexical verbs in that they are instances of v (see Folli and Harley 2007).11 My proposal is that where $\mathrm{v}$ is lexicalised it fails to inherit case features from Voice. These assumptions serve to derive the clitic only ECM pattern from the Phase Impenetrability Condition (PIC). Let us consider how.

First, consider an example where a verb of perception or permission selects an active ECM complement (a VoiceP). Phase heads are rendered in bold, for expository reasons:

$$
\text { [vP V[ACC] [vP voit/laisse [voiceP Voice [vP causee v [VP...]]]]] }
$$

Following the arguments in Sheehan and Cyrino (2018), I adopt the second, less restrictive version of the PIC, often labelled PIC2 (Chomsky 2001). PIC2 differs from the original PIC in Chomsky (2000) in allowing A-relations to be established in a 'window of opportunity' after a phase has been constructed before the next phase head is merged. This means that in (49), as only one phase head is present (Voice), none of the material in the lower vP has been transferred to the interfaces at this point in the derivation and so the matrix little $\mathrm{v}$, which inherits an ACC case feature can probe the causee and agree with it, assigning it accusative case and attracting it to the matrix clause, as outlined in the Section 3.1. In this example, the embedded VoiceP is active but nothing would change if it were passive as there would still be no phase boundary between the matrix $\mathrm{v}$ and the embedded arguments. Whether the causee is a clitic or a full DP, ECM is perfectly possible.

Now consider a minimally different scenario where the matrix verb is a light verb realising $\mathrm{V}$ rather than $\mathrm{V}$. In this case, by hypothesis, the light verb fails to inherit accusative case feaures and so Voice is the case-assigning head. For this reason, matrix Voice probes for a DP to Agree with and assign ACC case to. Where the complement of the light verb is nonphasal (a vP or VP), there is no phase boundary and so all arguments are accessible for case licensing. This is the case in both faire-infinitif and faire-par:

$$
\text { [VoiceP Voice[ACC] [vP fait [vP causee v [vP V DP]]]] }
$$

Where the light verb selects a phasal ECM complement, however, the problem is that there are now two phase heads in the structure and by the time the matrix Voice probes, all of the arguments of the embedded VoiceP have been spelled out. This makes all of the arguments of the embedded vP inaccessible for accusative case assignment: 
This explains why French faire 'make' does not permit full ECM. Where this verb functions as a causative, it always has the status of a light verb (little $v$ ) and light verbs are incompatible with full ECM.

The question remains, though, why ECM is possible in such contexts as long as the causee is a clitic (for some speakers, more in PCC contexts). My proposal is that clitics, unlike full DP arguments, escape the embedded phase by undergoing obligatory movement to matrix v. However cliticization is formalised, it can be observed that clitics undergo obligatory argument-related movement to a c-commanding verb in a local domain. This movement does not appear to be case-related, as in restructuring contexts we can observe optional clitic climbing. In this ECM context, is it obligatory with the accusative causee but blocked for lower arguments. All that is crucial in order to derive the effect in question is that local cliticization is a kind of movement which is unconnected to case assignment (see the different approaches to cliticisation in Sportiche 1996, Roberts 2010). The effect of cliticization is that clitic causees move out of the embedded vP and in doing so become accessible to matrix Voice. In a simple tense, we can assume that the clitic is simply attracted by $\mathrm{v}: 12$

\section{[voiceP Voicencc [vp le+fait [voiceP Voice [vp le v [VP...]]]]]}

It follows, then, that the only way for ECM to converge where the matrix verb is a light verb is for the accusative causee to be a clitic which, for independent reasons, raises into the domain of the accusative-case assigning head (matrix Voice).

Essentially, what I am proposing is that there are two crucial changes required in order for a verb to develop full ECM. First, there is a change in selection whereby a larger phasal VoiceP complement is permitted under a permissive/causative verb. Then, when such a complement is possible, a further change can take place whereby the selecting causative/permissive verb is reanalysed as a lexical verb as opposed to a light verb. It is only when this second change takes place that full ECM becomes possible. Why does the change in selection precede the change from light verb to lexical verb status? I propose that this is not necessarily the case. There is no evidence, from example that perception verbs go through a clitic ECM phase. Intuitively, perception verbs are more lexical than permissive verbs which are in turn more lexical than causatives, in terms of their semantics (see Higginbotham 1983). It is the latter two kinds of verbs that are most likely to be light verbs and hence to display the clitic ECM pattern. There is also a sense in which the more coercive semantics found in instances of ECM are suggestive of a more lexical use of the matrix verb. Recall the following contrast:

$$
\begin{aligned}
& \text { a. Le gardien a laissé le prisonnier s'échapper. } \\
& \text { the warden has let the prisoner SE=escape.INF } \\
& \text { 'The warden let the prisoner escape (intentionally).' } \\
& \text { b. Le gardien a laissé s'échapper le prisonnier. } \\
& \text { the warden has let SE=escape.INF the prisoner } \\
& \text { 'The warden let the prisoner escape (unintentionally).' }
\end{aligned}
$$

(Kayne 1975: 232)

12 There many unanswered questions here about the precise mechanics of cliticization and clitic climbing which I leave open, notably the question of how clitics end up associated with finite auxiliary verbs such as avoir/être. This is essentially the question of how clitic climbing is to be analysed, which I leave to one side here. 
In the ECM construction (53a), laisser 'let' has a more agentive reading, compatible with it being a lexical verb.

Note that in instances of clause union, the embedded complement is non-phasal and so accusative (and dative) case can be assigned by the matrix clause even if the matrix verb has the status of a light verb, as schematised in (50) (for a full analysis of these complements see Pineda and Sheehan 2020). Where the complement is non-phasal it makes no difference whether the matrix verb is V or v: the fact that there is no lower (Voice) phase head in this structure means that matrix Voice can access all arguments of the embedded vP. In short, the light verb status of the matrix verb has no implications for case assignment in instances of clause union, as there is no lower phase boundary. It is only where the complement of a causative/permissive/perception verb is itself phasal, that the light verb status of the matrix verb affects case assignment, giving rise to the clitic ECM pattern.

\section{The history of ECM in French}

Thus far, I have presented synchronic evidence for an intermediate step in the development of ECM which I have called clitic ECM. This pattern is observed in varieties of modern Italian, Catalan and French, raising the question of whether it is also attested historically in the cells in Table 5 (repeated here) in which full ECM is now available.

Table 5: distribution of ECM and FI complements

\begin{tabular}{|c|c|c|c|c|c|c|}
\hline & Italian & Catalan & French & Spanish & $\begin{array}{l}\text { E. } \\
\text { Portuguese }\end{array}$ & $\begin{array}{l}\text { B } \\
\text { Portuguese }\end{array}$ \\
\hline SEE & FI/ECM & FI/ECM & FI/ECM & FI/ECM & FI/ECM & ECM \\
\hline LET & $\begin{array}{l}\text { FI/ } \\
\mathrm{cl} \mathrm{ECM/} \\
\% \mathrm{ECM}\end{array}$ & $\begin{array}{l}\mathrm{FI} / \\
\mathrm{cl} \mathrm{ECM} \\
1 \% \mathrm{ECM}\end{array}$ & FI/ECM & $\mathrm{FI} / \mathrm{ECM}$ & FI/ECM & ECM \\
\hline MAKE & $\begin{array}{l}\text { FI/ } \\
\% \mathrm{cl} \mathrm{ECM}\end{array}$ & $\begin{array}{l}\text { FI/ } \\
\% \mathrm{cl} \text { ECM }\end{array}$ & $\begin{array}{l}\text { FI/ } \\
\% \text { cl ECM }\end{array}$ & $\begin{array}{l}\mathrm{FI} / \% \mathrm{ECM} / \\
\% \mathrm{cl} \text { ECM }\end{array}$ & $\overline{\mathrm{FI} / \mathrm{ECM}}$ & $\overline{\mathrm{ECM}}$ \\
\hline MANDARE & $\begin{array}{l}\text { prep. } \\
\text { infinitive }\end{array}$ & $*$ & $*$ & $\% \mathrm{FI}$ & FI/ECM & $\overline{\mathrm{ECM}}$ \\
\hline
\end{tabular}

As noted above, a paucity of data in Davies (1992) makes it difficult to draw conclusions about older stages of Portuguese, and two independent facts about Spanish (differential object marking and leísmo) make it impossible to observe whether Spanish also displayed such a tendency. In this section, I consider the history of French, in order to establish whether it displayed the clitic ECM pattern historically with laisser or voir. I begin by summarising previous work on the history of French causative/permissive/perception verbs by Pearce (1990) and Martineau (1990) and then present new data from the Base de Français Médiéval on the history of laisser.13

The Old French data described by Pearce (given here in Table 6) seem, on the surface, to support the idea that ECM developed first with verbs of perception. Verbs of perception overwhelmingly occur with intransitive verbs, but with transitives, both accusative and dative causees are attested in Old French, though numbers are very small. With the causative faire 'make' and the permissive laisser 'let', in Old French, 90\% of causees in transitive contexts

13 Pearce (1990) bases her study on 50 Old French texts. The parsed Base de Français Médiéval comprises 170 texts from IX - XVI centuries (see Guillot-Barbance, et al. 2017). There is minimal overlap between Pearce's corpus and the texts in the Base de Français Médiéval: the BFM includes OF texts not considered by Pearce, as well as later Middle French texts. 
are dative, suggesting that ECM emerged later, as described by Davies (1992) for Spanish and Portuguese.

Table 6: Dative causees with causative/permissive/perception verbs (Pearce 1990: 140)

\begin{tabular}{|l|l|l|l|l|l|l|}
\hline & \multicolumn{3}{|c|}{ Intransitive } & \multicolumn{3}{c|}{ Transitive } \\
\hline & ACC & DAT & \%DAT & ACC & DAT & \%DAT \\
\hline faire & 189 & 3 & $2 \%$ & 8 & 69 & $90 \%$ \\
\hline laisser/laier & 90 & 1 & $1 \%$ & 1 & 9 & $90 \%$ \\
\hline & & & & & & \\
\hline voir & 140 & 0 & $0 \%$ & 7 & 12 & $63 \%$ \\
\hline oür & 29 & 0 & $0 \%$ & 2 & 8 & $80 \%$ \\
\hline
\end{tabular}

Because the crucial context is transitive contexts with 3rd person causees, the numbers in Pearce's sample are very small for everything but faire, however, so there is reason to be cautious of the percentages in Table 5. The breakdown of clitic vs full DP by Pearce (shown in Table 7) paints a different picture of what is really going on in Old French. What this breakdown shows is that although full DP causees are much rarer overall than clitic causees, virtually all examples of accusative causees in transitive contexts are full DPs.14

Table 7: Case marking of DPs and clitic pronouns in transitive contexts (Pearce 1990: 149)

\begin{tabular}{|l|l|l|l|l|l|l|}
\hline & \multicolumn{3}{|c|}{ Accusative } & \multicolumn{3}{c|}{ Dative } \\
\hline & $\mathrm{DP}$ & pronoun & $\% \mathrm{DP}$ & $\mathrm{DP}$ & pronoun & $\% \mathrm{DP}$ \\
\hline faire & 7 & 1 & $88 \%$ & 24 & 45 & $35 \%$ \\
\hline laisser/laier & - & 1 & $0 \%$ & 2 & 7 & $22 \%$ \\
\hline & & & & & & \\
\hline voir & 7 & - & $100 \%$ & 3 & 9 & $25 \%$ \\
\hline ö̈r & 2 & - & $100 \%$ & 4 & 4 & $50 \%$ \\
\hline
\end{tabular}

The results in Table 7 are surprising given what we have seen above in synchronic varieties. Rather than a clitic ECM pattern, we seem to be observing a DP ECM pattern, whereby ECM is limited to contexts where the causee is a full DP for both causative and perception verbs.

It is likely that the examples of accusative causees in transitive contexts in Old French are not true examples of ECM, however. As Pearce (1990) notes, citing Herslund (1980), DPs often fail to be overtly marked for dative case in Old French in other contexts where we would expect it (see also Morin et St-Amour 1977; Martineau 1990). This is true, for example, when they function as recipients/goals:

(54) a. Ne ben ne mal ne respunt sun nevuld.

nor well nor bad NEG responds his nephew

'He responds neither well nor badly to his nephew.'

(Roland, 216, cited by Morin et St-Amour 1977:124)

b. Prestez vostre oncle et mon seignor vostre palefroi

lend your uncle and my lord your steed

'Lend your uncle and my lord your steed.'

(Vair, 795, Pearce 1990: 158, citing Herslund 1980)

14 I have modified Pearce's terminology minimally here for ease of exposition. 
This introduces a confounding factor into the French data with full DPs, making it impossible to tell whether ECM was really attested in Old French with these verbs. In fact, the virtual absence of ECM with pronominal causees suggests that it was perhaps not available.

Given the data presented by Martineau (1990) for Middle French from two texts from the Cent Nouvelles Nouvelles (late 15c), the most likely scenario is that it was not, at least not with faire. The data presented by Martineau are summarised in Table 8.

Table 8 Case patterns with causative/permissive/perception verbs in the Cent Nouvelles Nouvelles (Martineau 1990: 81, 83)

\begin{tabular}{|l|l|l|l|l|}
\hline & $\begin{array}{l}\text { dative pronouns in } \\
\text { intransitive } \\
\text { contexts }\end{array}$ & $\begin{array}{l}\text { dative pronouns in } \\
\text { transitive contexts }\end{array}$ & $\begin{array}{l}\text { Dative DPs in } \\
\text { intransitive } \\
\text { contexts }\end{array}$ & $\begin{array}{l}\text { Dative DPs in } \\
\text { transitive } \\
\text { contexts }\end{array}$ \\
\hline faire & $2 \%(2 / 90)$ & $96 \%(69 / 72)$ & $0 \%(0 / 76)$ & $97 \%(28 / 29)$ \\
\hline laisser & $3 \%(1 / 30)$ & $67 \%(8 / 12)$ & $0 \%(0 / 11)$ & $40 \%(4 / 10)$ \\
\hline ouyr & $0 \%(0 / 9)$ & $33 \%(1 / 3)$ & $0 \%(0 / 24)$ & $57 \%(12 / 21)$ \\
\hline voir & $0 \%(0 / 29)$ & $0 \%(0 / 3)$ & $0 \%(0 / 52)$ & $8 \%(1 / 13)$ \\
\hline
\end{tabular}

Although numbers are again small, a clear contrast emerges in Middle French between faire on the one hand, which appears not to permit ECM and the other verbs, which display ECM with both clitics and full DPs, indicated by the lower percentages for datives in transitive contexts. There is no evidence in these data for the clitic ECM pattern, however. Rather ECM seems to be available with all four verbs regardless of the kind of causee. It would appear then, that these texts from the late 15 th century are too late for us to observe the clitic ECM pattern.

Pearce reports only one example of ECM with laisser (from Le roman de Rou de Wace, 1160-70), but this is one of only ten transitive examples with laisser in her corpus. It is interesting to note that this example involves a clitic causee:

ne le voudrent lessier, [...]/ lor villes essillier et lor mesons ardoir,
NEGhim. ACC wanted.3pl let, their towns ruin and their houses burn
'...did not want to let him ruin their towns and burn their houses.'

A lemma search of the Base de Français Médiéval 2019 using the forms cited in Dictionnaire du Moyen Français (1330-1500) http://www.atilf.fr/dmf/ brings up 4471 hits for laisser:

(56) [lemma contains "laisser|laier|layer|laissier|lesser|laxare"]

To isolate tokens followed by an infinitive and including an overt causee preceding or following laisser, we can search for:

[cattex-pos="PROper|NOMcom|NOMpro"] [ ]* [lemma contains

"laisser|laier|layer|laissier|lesser|laxare"] [ ]* [cattex-pos="VERinf"] within 5

1155 hits in the BFM2019

[lemma contains "laisser|laier|layer|laissier|lesser|laxare"] [ ]* [cattex-

pos="PROper|NOMcom|NOMpro"] [ ]* [cattex-pos="VERinf"] within 5

490 hits in the BFM2019

The 1645 examples were then manually categorised to isolate instances where the infinitive is transitive and the causee 3rd person and sorted for type (DP/clitic) and case (ACC/DAT). The results for Old French are as we might expect, in that they mirror the results reported by 
Pearce for faire. The Middle French results are, however, different, showing a potential skewing towards clitic ECM.

Table 6: laisser in Old and Middle French texts from the Base de Français Médiéval 2019

\begin{tabular}{|l|l|l|l|l|l|l|}
\hline & \multicolumn{3}{|c|}{ Accusative } & \multicolumn{3}{c|}{ Dative } \\
\hline & DP & clitic & $\%$ DP & DP & clitic & $\%$ DP \\
\hline $\begin{array}{l}\text { Old } \\
\text { French }\end{array}$ & 4 & 2 & $67 \%$ & 3 & 15 & $17 \%$ \\
\hline $\begin{array}{l}\text { Middle } \\
\text { French }\end{array}$ & 1 & 4 & $20 \%$ & 2 & 7 & $16 \%$ \\
\hline
\end{tabular}

In Old French, I have been able to identify four accusative DP causees in transitive contexts vs three dative DPs. This includes one minimal pair in the same text:

a. Que nus laissum le mort Ensevelir le mort. that we let.1PL the dead bury the dead '...that we let the dead bury the dead.'

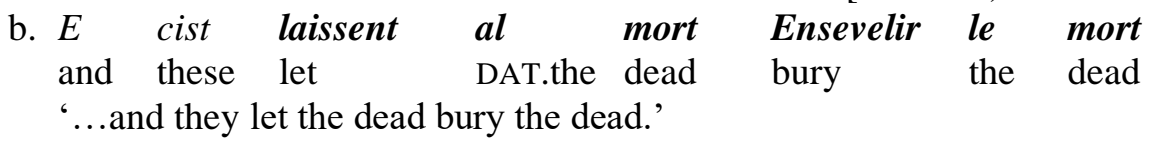

[bestiaire, 1121-1135, p. 48, v. 1294]

Example (57b) lends support to the idea that (57a) is not a real example of ECM but rather an instance of covert marking of dative case on full DPs, as the meaning of these two examples seems identical.

By Middle French, genuine ECM has begun to develop with clitics, and I have only been able to identify one example with a full DP causee.

(58) [...] car l' empereor ne laissoit nul de ses chapitaines passer $l^{\prime}$ année for the emperor not let.imperf none of his captains pass the year 'For the emperor did not let any of his captains last more than one year...'

[moree, 1320-1324, p 240]

The majority of Middle French examples involve clitics, as one would expect if early Middle French passed through a clitic ECM phase.

(59) [...] pour quoy Abilant ne le laissa point faire la jouste,

for what Abilant not him let neg do the joust

'...why Abilant does not let him joust,'] [berin1, 1370, p. 339]

(60) [...] s'il ne veult, le laisse Faire la guerre,

if he not wants him let make the war

'...and is he doesn't want to, let him go to war,' [ressource, 1498, p. 132, v. 1061]

Although few transitive infinitives under laisser with a 3rd person causee are available in the Base de Français Médiéval 2019, there are more examples than in the corpus used by Pearce and comparable numbers to those in Martineau's late Middle French texts. The numbers suggest that French laisser most probably passed through a clitic ECM phase in early Middle 
French before full ECM became available, in parallel with what can be observed in present day Italian and Catalan. Of course, clitic causees are more common than full DP causees with laisser, so this must also be considered.

\section{Conclusions}

In this article, I have argued for the existence of a clitic ECM stage in the development of ECM. This can be observed in several modern Romance varieties and it may also have existed in Middle French with the verb laisser, though the available data are limited. The explanation for this pattern, I have argued, can be found in phase theory, more specifically, the PIC. Because laisser/faire are light verbs, where they select a phasal complement, the PIC blocks accusative case assignment except in instances where a clitic raises into the matrix phase for independent reasons (i.e. cliticization). The full ECM pattern only becomes possible when the matrix verb laisser/faire is reanalysed as a lexical verb with concomitant semantic changes.

\section{References}

Abeillé, Anne, Danièle Godard \& Philip Miller. 1997. Les causatives en français : un cas de compétition syntaxique. Langue Française 115 : 62-74.

Adger, David. 2003. Core Syntax: a minimalist approach. OUP

Aelbrecht, Lobke, \& William Harwood. 2015. To be or not to be elided: VP ellipsis revisited. Lingua 153: 66-97.

Aissen, Judith, \& David Perlmutter. 1976. Clause reduction in Spanish. In Henry Thompson et al. (eds.), Proceedings of the Second Annual Meeting of the Berkeley Linguistic Society. Berkeley: University of California, Berkeley Linguistic Society, 1-30.

Alsina, Alex. 1992. On the argument structure of causatives. Linguistic Inquiry 23:517-555.

Alsina, Alex. 1997. A theory of complex predicates: evidence from causatives in Bantu and Romance. In Alex Alsina, Joan Bresnan and Peter Sells (eds.), Complex Predicates, 203246. Stanford: CSLI Publications.

Alsina, Alex. 2002/2008. L'infinitiu. In Joan Solà et al. (ed.), Gramàtica del català contemporani. Barcelona: Empúries.

Anagnostopoulou, Elena. 2003. The syntax of ditransitives. Berlin: Mouton de Gruyter.

Anagnostopoulou, Elena. 2005. Strong and weak person restrictions: a feature checking analysis. In Lorie Heggie \& Francisco Ordóñez (eds.), Clitic and affix combinations: theoretical perspectives, 199-235. Amsterdam: John Benjamins.

Authier, J.-Marc \& Lisa Reed. 1991. ergative predicates and dative cliticization in French causatives. Linguistic Inquiry 22:197-205.

Bailard, Joële. 1982. The interaction of semantic and syntactic functions and French clitic case marking in causative sentences. In Paul J. Hopper et Sandra. A. Thompson (eds.), Syntax and Semantics 15: Studies in Transitivity, New York, Academic Press, pp. 49-69.

Belletti, Adriana \& Luigi Rizzi. 2012. Moving verbal chunks in the low functional field. In Laura Brugè, Anna Cardinaletti, Giuliana Giusti, Nicola Munaro \& Cecilia Poletto (eds.), Cartography of Syntactic Structures, 7129-137. Oxford: OUP.

Bjorkman, Bronwyn. 2011. BE-ing default: The morphosyntax of auxiliaries. Cambridge, MA.: MIT dissertation.

Bonfim, Manoel \& Heloisa Salles. 2016. Causativas ECM e controle reverso: uma proposta para o português brasileiro. Estudos linguísticos 44:110-125.

Bonet, Eulalia. 1991. Morphology after syntax: pronominal clitics in Romance. Ph.D. thesis, MIT. 
Bordelois, Ivonne. 1988. Causatives: from lexicon to syntax. Natural Language and Linguistic Theory 6: 57-93.

Burzio, Luigi. 1986. Italian syntax. a Government-Binding approach. Dordrecht: Reidel.

Chomsky, Noam. 2000. Minimalist inquiries: the framework. In Roger Martin, David Michaels \& Juan Uriagereka (eds.), Step by step, 89-156. Cambridge, MA: MIT Press.

Chomsky, Noam. 2001. Derivation by phase. In Michael Kenstowicz (ed.), Ken Hale: A Life in Language, 1-52. Cambridge, MA: MIT Press.

Chomsky, Noam. 2008. On phases. In Robert Freidin, Carlos P. Otero, and Maria Luisa Zubizarreta (eds.), Foundational issues in linguistic theory: Essays in honor of JeanRoger Vergnaud,133-166. Cambridge, MA: MIT Press.

Cinque Guglielmo. 2003. The Interaction of Passive, Causative, and "Restructuring. In Christina Tortora, The Syntax of Italian Dialects, New York, Oxford University Press

Ciutescu, Elena. 2013. Remarks on the infinitival subject of perception verb complements: evidence for two syntactic configurations. Revue Roumaine de Linguistique no. LVIII(3): 299-312.

Ciutescu, Elena. 2018. Defective causative and perception verb constructions in Romance. A minimalist approach to infinitival and subjunctive clauses. Barcelona: University of Barcelona dissertation.

Coon, Jessica \& Stefan Keine. 2020. Feature gluttony. https://ling.auf.net/lingbuzz/004224

Cyrino, Sonia. 2010a. On Romance syntactic complex predicates: why Brazilian Portuguese is different. Estudos da Língua(gem) 8:187-222.

Cyrino, Sonia. 2010b. On complex predicates in Brazilian Portuguese. Iberia: An International Journal of Theoretical Linguistics 2:1-21.

Danell, Karl Johan. 1979. Remarques sur la construction dite causative. Stockholm: Almqvist et Wiksell.

Davies, Mark. 1992. The diachronic evolution of causative constructions in Spanish and Portuguese. Austin: University of Texas dissertation.

Davies, Mark. 1995. The evolution of causative constructions in Spanish and Portuguese. In Jon Amastae, Grant Goodall, Mario Montalbetti and Marianne Phinney (eds.), Contemporary research in Romance linguistics, 105-122. Amsterdam: John Benjamins.

Folli, Raffaella \& Heidi Harley. 2007. Causation, Obligation, and Argument Structure: On the Nature of Little v. Linguistic Inquiry 38:197-238.

Gonçalves, Anabela. 1999. Predicados complexos verbais em contextos de infinitivo não preposicionado do Português Europeu. [Complex verbal predicates in the context of non prepositional infinitives in European Portuguese] Lisbon: University of Lisbon dissertation.

Grevisse, Maurice. 1969. Le bon usage. 9th ed. Gembloux: J. Duculot.

Guasti, Maria Teresa, 1993. Causative and perception verbs: a comparative study. Torino: Rosenberg \& Sellier.

Guasti, Maria Teresa. 1996. Semantic restrictions in Romance causatives and the incorporation approach. Linguistic Inquiry 27:294-313.

Guasti, Maria Teresa. 2017. Analytical Causatives. In Martin Everaert and Henk C. van Riemsdijk (eds.), The Wiley Blackwell companion to syntax, Second Edition (eds). doi:10.1002/9781118358733.wbsyncom038

Guillot-Barbance, Céline, Serge Heiden \& Alexei Lavrentiev. 2017. Base de français médiéval : une base de référence de sources médiévales ouverte et libre au service de la communauté scientifique. Diachroniques 7 :168-184. 〈halshs-01809581〉

Harley, Heidi. 2013. External arguments and the Mirror Principle: On the distinctness of voice and v. Lingua 125: 34-57. 
Harley, Heidi. 2017. The "bundling" hypothesis and the disparate functions of little v. In Roberta D'Alessandro, Irene Franco and Angél J. Gallego (eds.), The verbal domain, 328. Oxford: OUP.

Harwood William. 2015. Being progressive is just a phase: celebrating the uniqueness of progressive aspect under a phase-based analysis. Natural Language \& Linguistic Theory 33 (2): 523-573.

Herslund, Michael. 1980, Problèmes de l'ancien français. Compléments datifs et génitifs. Revue Romane. Numero special 21.

Higginbotham, James. 1983. The logic of perceptual reports: An extensional alternative to situation semantics. Journal of Philosophy 80(2): 100-127.

Hornstein, Norbert, Jairo Nunes \& Ana Maria Martins. 2010. Perception and Causative Structures in English and European Portuguese. Syntax 11(2): 205-229.

Hyman, Larry \& Christian Zimmer. 1976. Embedded topics in French. In C. Li (ed.), Subject and Topic. New York: Academic Press.

Kayne, Richard S. 1975. French syntax: the transformational cycle. Cambridge, MA.: MIT Press.

Kayne, Richard S. 1981. On Certain Differences between French and English. Linguistic Inquiry 12(3):349-371.

Labelle, Marie. 1996. Remarques sur les verbes de perception et la sous-categorisation. Recherches Linguistiques de Vincennes 25:83-106.

Legate, Julie Anne. 2003. Some Interface Properties of the Phase. Linguistic Inquiry 34: 50616.

Martineau, France. 1990. La construction « accusatif avec infinitif » avec les verbes causatifs et de perception en moyen français. Revue québécoise de linguistique 19 (1): 77-100.

Martins, Ana Maria 2004. Ambiguidade estrutural e mudança linguística: A emergência do infinitivo flexionado nas orações complemento de verbos causativos e perceptivos. [Structural ambiguity and language change: the emergence of the inflected infinitive in the complements of causative and perception verbs]. In Ana-Maria Brito, Olívia

Figueiredo \& Clara Barros (eds.), Linguística histórica e história da língua Portuguesa: actas do encontro de homenagem a Maria Helena Paiva, 197-225. Porto: Universidade do Porto.

Martins, Ana Maria 2018. Infinitival complements of causative/perception verbs in a diachronic perspective. In Anabela Gonçalves \& Ana Lúcia Santos (eds.), Complement clauses in Portuguese: syntax and acquisition, 101-128. Amsterdam/Philadelphia: John Benjamins.

McGinnis, Martha. 2004. Lethal ambiguity. Linguistic Inquiry 35: 47-95.

Merchant, Jason. 2013. Voice and ellipsis. Linguistic Inquiry 44(1):77-108/

Morin, Yves-Charles \& Marielle St-Amour. 1977. Description historique des constructions infinitives du français, Recherches Linguistiques à Montréal 9 :113-152.

Nevins, Andrew Ira. 2007. The representation of third person and its consequences for Person-Case effects. Natural Language and Linguistic Theory 25: 273-313.

Pearce, Elizabeth. 1990. Parameters in Old French syntax: infinitival complements. Kluwer: Dordrecht.

Pineda, Anna and Michelle Sheehan. 2020. A Multiple Agree account of the Romance faireinfinitive: new evidence from Catalan. Unpublished ms.

Postal, Paul M. 1981. A failed analysis of the French cohesive infinitive construction. Linguistic Analysis 8: 281-323.

Postal, Paul. M. 1989. Masked inversion in French. University of Chicago Press: Chicago.

Pylkkänen, Liina. 2008. Introducing arguments. Cambridge, MA: MIT Press.

Quicoli, A. Carlos. 1984. Remarks on French clitic systems. Linguistic Analysis 14: 55-95. 
Ramchand, Gillian \& Peter Svenonius. 2014. Deriving the functional hierarchy. Language Sciences 46:152 - 174.

Reinhart, Tanya. 1996. Syntactic effects of lexical operations: reflexives and unaccusatives. UiL OTS Working Papers in Linguistics. Utrecht Institute of Linguistics.

Reinhart, Tanya \& Tal Siloni. 1999. Against the unaccusative analysis of reflexives. In Artemis Alexiadou, Elena Anagnostopoulou, \& Martin Everaert (eds.) The Unaccusativity Puzzle. Oxford: Oxford University Press.

Rezac, Milan. 2008. The syntax of eccentric agreement: the Person Case Constraint and absolutive displacement in Basque. Natural Language \& Linguistic Theory 26(1): 61106.

Rezac, Milan. 2009. On the unifiability of repairs for the Person Case Constraint: French, Basque, Georgian and Chinook. Hasiera 1-2 https://www.ehu.eus/ojs/index.php/ASJU/article/view/1756

Rizzi, Luigi. 1986. On Chain Formation. In Borer, Hagit (ed),Syntax and SEmantics 19: The Syntax of Pronominal Clitics. New York: Academic Press.

Roberts, Ian. 2010. Agreement and head movement. MIT Press.

Rooryck. Johan. 2000. Configurations of sentential complementation: perspectives from Romance. New York: Routledge.

Rosen 1992. The case of subjects in the Romance causative. Kansas Working Papers in Linguistics 17(1): 79-114.

Ross, Haj. 1967. Constraints on variables in syntax. MIT dissertation.

Sailor, Craig. 2014. The variables of VP ellipsis. Los Angeles: UCLA dissertation.

Santorini, Beatrice \& Caroline Heycock. 1988. Remarks on causatives and passives. Ms., University of Pennsylvania.

Schäfer, Florian. 2017. Romance and Greek medio-passives and the typology of Voice. In Roberta D'Alessandro, Irene Franco, and Ángel J. Gallego (eds.), The Verbal Domain. OUP.

Schifano, Norma \& Michelle Sheehan. 2018. Italian faire-infinitives: the special case of volere. In Mirko Grimaldi, Rosangela Lai, Ludovico Franco and Benedetta Baldi (eds), Structuring variation in Romance linguistics and beyond, 161-175. Amsterdam: John Benjamins.

Sheehan, Michelle. 2020. The Romance Person Case Constraint is not about clitic clusters. In A. Pineda, J. Mateu \& R. Etxepare (eds.). Dative structures in Romance and beyond (Open Generative Syntax). Berlin: Language Science Press, 139-170.

Sheehan, Michelle \& Sonia Cyrino. 2016. Variation and change in the faire-par causative. In Ernestinha Carrilho, Alexandra Fieis, Maria Lobo \& Sandra Pereira (eds.), Romance Languages and Linguistic Theory, 279-304. John Benjamins.

Sheehan, Michelle \& Sonia Cyrino. 2018. Why do some ECM verbs resist passivisation? A phase-based explanation. In Sherry Hucklebridge \& Max Nelson (eds.), Proceedings of NELS 48 (vol 3), 81-90. University of Massachusetts.

Solà, Joan. 1994. Sintaxi normativa: estat de la qüestió. Barcelona: Empúries.

Sportiche Dominique. 1996. Clitic Constructions. In Johan Rooryck, Laurie Zaring (eds.), Phrase Structure and the Lexicon. Studies in Natural Language and Linguistic Theory, vol 33. Springer, Dordrecht, 213-276.

St-Amour, Marielle. 1983. Les compléments verbaux du latin classique à l'ancien français. Montréal : Université de Montréal dissertation.

Strozer, Judith. 1976. Clitics in Spanish. Los Angeles: UCLA dissertation.

Torrego, Esther. 1998. The Dependencies of Objects. London; Cambridge, MA: MIT Press.

Torrego, Esther. 2010. Variability in the case patterns of causative formation in romance and its implications. Linguistic Inquiry 41: 445-470. 
Treviño, Esthela. 1994. Las causativas del español con complemento de infinitivo. Mexico City: Colegio de México dissertation.

Tubino Blanco, Mercedes. 2010. Contrasting Causatives: a Minimalist Approach. Tucson: University of Arizona dissertation.

Villalba, Xavier. 1992. Case, incorporation, and economy: an approach to causative constructions. Calalan Working Papers in Linguistics 1: 345-389.

Wurmbrand, Susi. 2012. The syntax of valuation in auxiliary-participle constructions. In Jaehoon Choi, E. Alan Hogue, Jeffrey Punske, Deniz Tat, Jessamyn Schertz, and Alex Trueman (eds.), Proceedings of the 29th West Coast Conference on Formal Linguistics (WCCFL 29), 154-162. Somerville, MA.: Cascadilla Press.

Zubizarreta, María Luisa. 1985. The relation between morphophonology and morphosyntax: the case of Romance causatives. Linguistic Inquiry 16:247-289. 